\title{
Local Economic Development Tourism Village on the slopes of Mount Merapi (Case Study in Balerante Village Community Kemalang District Klaten District)
}

\author{
Djoko Puguh Wibowo \\ The Ministry of Rural Development Rural and Transmigration \\ Jakarta, Indonesia \\ dpwibowo@gmail.com \\ Bernadin Dwi M \\ Faculty of Economic and Business \\ Universitas Pembangunan Nasional Veteran Jakarta \\ Jakarta, Indonesia \\ bernadindwim@yahoo.com \\ Miguna Astuti \\ Faculty of Economic and Business \\ Universitas Pembangunan Nasional Veteran Jakarta \\ Jakarta, Indonesia \\ Corresponding Author Email: miguna.astuti@upnvj.ac.id \\ DOI: 10.31364/SCIRJ/v6.i11.2018.P1118580 \\ http://dx.doi.org/10.31364/SCIRJ/v6.i11.2018.P1118580
}

\begin{abstract}
The eruption of Mount Merapi in 2010 makes the landscape of the southern slopes have uniqueness and natural charm that encourages people to develop tourism. Tourist developments tend to decline as a result of the management is done by partial and not yet included the community as the main actor. The study was conducted in Balerante village located on the South slope of Merapi. Objective: identify tour players, of the economic potential of local and formulate strategies Balerante Village travel development. The research is done through Descriptive, Qualitative and Case Studies. The analysis focuses on the principles and stages screwed Local Economic Development (LED) or a Local Economic Development (LED). The results showed, the position Balerante village and tourist resort located in disaster prone areas and special areas so that the model developed travel to be part of the mitigation and conservation, and increasing the competitiveness of the local economy. To that end, the vision of its development strategy to be achieved is Brought Desa Balerante As Desatinasi CommunityBased Ecotourism, through three strategies, namely: Developing a Tourism Village Nature and Culture, Creating Sustainable and Resilient Balerante Village Disaster and Achieve Competitive Local Economy. Key to the success of the development is the commitment of the Government and Parties, the ability of managers to innovate through the differentiation and diversification of tourism products, as well as integrated promotion.
\end{abstract}

Index Terms: Ecotourism, mitigation, Local Economic Development, integrated campaign

\section{INTRODUCTION}

Merapi eruption has changed the landscape which very different from the previous forms. Pile of material in the form of a sea of sand and rock, along the Gendol River, Kali Woro, and a new ecosystem has formed an amazing natural hue in the appeal compared to the eruption of Merapi natural conditions in 2010. The changes itself encourage the community initiatives of Kepuharjo Village, Pentingsari, Petung, and Glagaharjo village in the district of dives, and Sidomulyo also Klaten district Balerante which develop the region as a tourist's village nature with travel Icons of Merapi. The "Volcano Tour" Travel, Umbulharjo Village Government administered together with other developing villages' "Merapi Tour Icons". Similarly, the natural tourism that thrives in Desa Balerante, Deles and Sidorejo has become a tourist destination which includes the mountain bike, climbing including its natural attractions. The growth of these activities is capable of creating and expanding business opportunities for the people who work either through car and motorcycle rentals, tourist guides and food stalls and retribution in order to increase the income of citizens and the competitiveness of the region.

In the development of "Volcano Tour" which is the main tourism on the slopes of Merapi and its tourism activities have tended to decrease. Likewise, villages that only rely on the uniqueness of Merapi's charm tend to experience its slow development. On the other side, on the slopes of Merapi, there 
are varieties of economic potential which can be used as tourist attractions, unfortunately; it has not been managed optimally.

Some of the factors that make the decreasement and underdeveloped villages Merapi travel due to: first, as time goes by, the ecosystem of Merapi experience its recovery. Second, tourism management is done partially. Third, tourist attractions "volcano tour", agro tourism, culinary, disaster museum and home stay is still managed partially and not yet integrated into one or several tour packages. Fourth, the development of tourism in the institutional Merapi is not structured to forge any collaborations and partnerships between government, community and specialty travel agencies as well as with other parties. Fifth, the lack of promotion and marketing needs to be facilitated with the right marketing strategy (Edy Susilo, M., Prayudi and Heti Erawawi, 2016).

The research result Andrej Udovc, Anton Perpar (2007), shows that the development or diversification of products tourist village does not guarantee a higher stability, robustness, and integrity but also influenced by the size of the region and the diversity of actors involved (partnership) and developed governance. This is confirmed by Irshad, Humaira (2010), that the success of rural tourism besides influenced by the role of local community, but also determined by the structured network and collaborative or partnership agreement between the public sectors and private as well as the promotion and intensive marketing challenge to develop tourist villages with an object diversity as one of the pillars of national travel industry (Indonesia) are competitive through the management of tourist villages with a variety of potential natural, social and community-based environment.

Tourism Village is one form of initiative and creativity of the community who develops the potential of the village resources and aims to improve the economy and competitiveness of the region. Tourism Village is tourist destination/destinations, which integrate tourist attraction, public facilities, tourism facilities, accessibility, the structured society that is fused by the procedures and the prevailing tradition (Law 10/2009, the Ministry of Cooperatives and SMEs 2015). The Growth of interest in the people/travelers who travels to the remote areas to enjoy and learn about nature, history, and helping the local people's economic community and supporting the conservation of the environment or known as Ecotourism. This activity is not limited by the interest to enjoy the attractions, but also as an opportunity to make observations, meaning a thorough observations research on the uniqueness of the village as a tourist destination (Dep. Of Culture and Parwisaya and WWF, 2009).

General characteristics of eco-tourism agreed upon by several parties are as follows: to appreciate the nature and culture of indigenous, minimizing negative environmental and socio-cultural impacts, to help the economy directly and create an expansion of the local people's work, containing education and interpretation as part of deals, as well as raising the awareness local and conservation visitors (Ministry of Culture and Parwisaya and WWF, 2009, Suansri, P. 2003, Ministry of Cooperatives and MSMEs, 2015) Responding from the issue of the perpetrators and tourism activists agreed to emphasize that eco-tourism patterns should minimize negative impacts on environment (culture, physical economy) but also able to increase income and prosperity of society and contain conservation value or Community-Based Ecotourism Model.
Conceptually, Community-Based Ecotourism is used to describe various tourism models that involve the community participation and aim to generate benefits for local communities. Therefore, community participation (from cooperatives, individual companies, joint ventures between individuals between the public and other public private sectors) in tourism is the key word for the entire definition in Community-Based Ecotourism. Thus, local communities have a great control and involvement in the development and management, and most of the benefits remain in society (Lucchetti, Veronica Garcia, Xavier Font. 2013, Denman, Richard 2001).

Looking from some models of tourism development since the decade of the 90's, some people give a strong impetus through initiatives approach Local Economic Development (LED) or a Local Economic Development (LED) as an effort to putting local people as actors and the main beneficiaries of the developed activities (Pose , Rodríguez, Sylvia Tijmstra 2005)

There are various definitions of PEL from various circles. World Bank (2010), defines LED is a local economic development process aimed at building the economic capacity of a region to improve its economic future and quality of life for all. The process is implemented in partnership with the public sector, business and non-governmental sectors to work collectively to create better conditions for the growth of the economic and job creation (WORLD BANK, 2010). According to the Ministry of Public Works in the References of Local Economic Development (2012), who defines LED as the establishment of collective cooperation between government, business and non-government sectors and communities to identify and optimally utilize the resources they possess in order to stimulate and create a strong local economy, independent and sustainable. In practice, LED can be implemented on different geographical scales. In stages, the government can develop a LED strategy for the Regency/City region, while the village area can be the target area of LED for the Local Government/district in order to enhance the competitiveness of the region/village within its territory. PEL as the strategy for regional development should ideally become one part of a regional development plan (World Bank 2010). Viewed from the stage, LED stage is divided into five stages: Stage I: Organizing the effort, Phase II: Assessment of local potential, Phase III: Strategy Preparation, Phase IV: Implementation of the strategy, and Phase V: Review of strategy (monitoring and evaluation).

Balerante Village is located on the slopes of South Merapi and its territory is included in Disaster Prone Areas (KRB) since 2016 developed a tour that occupies the area of Mount Merapi National Park and has not been referring to the model in accordance with local character and environment.

\section{Methodology}

This research uses Descriptive and Qualitative approach Methods Case Studies. In this study, Descriptive Method is designed to collect information about the real and present situation (while underway). The use of this method aims to describe the nature of a state which is running at the time and check the cause of a particular symptom (Travers, 1978 in Sevilla et al, 1993).

According to Amirin (2000), Qualitative Methods are research related to qualitative data, ie data expressed in 
symbolic forms such as statements of interpretation (perception), literal oral responses and graphs. Given the data that is natural (reasonable), it will provide the possibility of reflecting the very relationships that occur in certain situations. One approach to obtaining qualitative information can be made using selected or selective individuals in discussion groups and directed at discussions focused on specific topics (Coeder, 1977, in Daim Sudarwan, 2000). Sevilla further explained that the case study is a detailed study of a particular case of research over a certain period. In this study, the case to be studied is emphasized on the analysis of Local Economic Development as a process of development of Balerante Village Village Village. The focus of the study is focused on the analysis of the resources potential of Balerante Village, stakeholders, development challenges and development strategies it needs to be taken by every involved actor.

The type of data needed in this study is secondary data and primary data. Secondary data retrieval technique is done through literature study and recording that has been done by various parties related to the topic. While at the secondary data location level obtained from the Office District and village. The primary data is done through group discussions involving interested parties (stakeholders) are Local Government through the relevant technical agencies, the private sector, and NGOs element selected communities. Primary data collection is also done through structured interviews with agency officials and related parties using questionnaires/interview guides. In addition to structured interviews, there will also be in-depth interviews of key informants and field observations.

In this research the analysis focused on 3 stages of LED that is stage To formulate development strategy of development of Tourism Village in Balerante (Phase III from LED) will be done qualitative analysis to vision, strategy, objective, program, and activity of purpose based on local economic appraisal result, development challenges taking into account local environmental conditions. Given the concept of LED has a wide scope to sharpen its development strategy formulation through limited discussions with key figures at the village / local level and related institutions, as well as other parties with special competence and knowledge in the field of tourism and disaster.

\section{RESULT AND DISCUSSION}

LED as a development strategy is a process for optimizing local resources and having an impact on sustainable economic and social growth. Implementation of LED through the 5 stages performed is a step by step process that must be executed as a precursor to the success of the goals and objectives set. In order to accelerate the development of Balerante Village tourism, this discussion will describe the steps of LED: Institutional covering: identification of the parties involved and their roles and functions, identification of local economic potentials, development challenges. The results of the analysis on the LED aspects are taken into consideration for the development strategy of accelerating the development of Balerante Tourism Village.

\section{Organizing Enterprises}

To plan and implement LED, the process of identifying the offender is the first step to be taken. Perpetrators are organizations or individuals who have the competence and commitment will contribute in generating strategic planning as the basis for achieving the goals that will be achieved. Successful collaboration between actors (government, private and non-governmental) is one of the key successes of LED to generate a profitable long-term partnership (Swinburn, G. 2006).

Implementation of the parties as actors in Balerante Village Development can be grouped into 4 groups, namely the local level as the main actors consisting of Dea Government, Community Groups led by the village youths who are members of the DRR and POKDRWIS groups, the household economic business group led by housewives, and village economic institutions, namely Village Owned Enterprise (BUMDES). At the local level actors identified to have a role as a facilitator for the acceleration is technical agencies. Non-governmental groups are individuals and groups committed to tourism development in Balerante. The category is a network formed through personal relationships with community leaders.

Table 1. Identify Actors of Acceleration of Balerante Village Tourism Development

\begin{tabular}{|c|c|c|c|}
\hline Local Level & District government & Non Government & Private \\
\hline \begin{tabular}{|l|} 
- \\
Balerante \\
Government \\
- Aware Awareness Group \\
(POKDARWIS) \\
- Disaster Risk Reduction \\
Group (DRR) \\
- Economic Business Group \\
- Conservation Groups \\
- Public figure \\
- BUMDes \\
- Manager of Mount Merapi \\
National Park (TNGM) \\
Kemalang Resort
\end{tabular} & 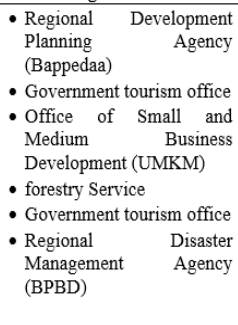 & \begin{tabular}{|llr} 
- & Mountain & Bike \\
& Community 10 AM \\
& (Klaten) \\
- & SPEKHAM (Surakarta) \\
- & Tourism activist \\
- & Researchers
\end{tabular} & $\begin{array}{ll}\text { Electronic } \\
\text { Media } \\
\text { District }\end{array}$ \\
\hline
\end{tabular}

Source: Primary Data Analysis

\section{Assessment of Local Economic Potential of Balerante Village}

\section{a. Village Authority}

With the enactment of Law No. 6 of 2014 on Villages (Law $6 / 2014$ ), all villages including Balerante have the authority and authority to plan and implement development in accordance with the potential resources and needs of the community (Chapter IV Article 19 through Article 22 of Law 6/2014 ). As a form of recognition and appreciation of the village, each village gets the allocation of development costs in the form of financial transfers through the Village Fund (DD) as well as financing the government (district / city, central and sector) devolved development, as well as village original income (PA Des).

\section{b. Geographic and Administrative Territories}

Balerante Village is one of the villages included in Kemalang District, Klaten Regency, Central Java Province. Area of 831.1230 ha, and located at an altitude of approximately $1.050 \mathrm{~m}$ above sea level (asl). The boundaries of Balerante Village are as follows: West side: bordering Glaharjo Village Sleman Province Special Province of Yogyakarta, North: bordering Mount Merapi National Park, East: bordering on Woro River, West side: bordering Panggang Village.

Administratively it consists of 15 hamlets namely: Balerante, Banjarejo, Banjarsari, Bendorejo, Bendosari, Guwosari, Gondang, Kaligompyong, Karangrejo, Ngelo, Ngipikari, Pusung, Sambungrejo, Sukorejo, Tegalweru. The Balerante village has open accessibility, can be reached by 4 wheel vehicles through paved roads from Yogyakarta and Klaten. In the framework of tourism development, located in the area of Yogyakarta's natural tourist area connected to 
Kaliurang tourism destination, Kepuharjo (Vulcano Tour), and adjacent to Glaharjo Village, cultural tourism area of Prambanan Temple and Boko Site, and the attractions of Deles Village, Sidomulyo as the starting point climbing Mount Merapi.After the eruption of Merapi in 2010, through Presidential Peratran No. 70 of 2014 on Rebcaa Spatial Area Strategic. The Balerante Village is included in the Raan Bencana III, and 5 Dusun areas: Sambirejo, Ngipiksari, Gondang, Banjarsari and Sambung Rejo are in the Directly Affected Area (ATL).

\section{c. Environment}

Balerante Village as one of the highest on the southern slopes of Merapi has a diversity of potential resources. After the eruption of 2010, the new landscape impact of the eruption formed a different landscape. The Woro River in the eastern part of the village becomes one of the tourism potentials, as well as the biodiversity (orchids, moss, endemic flower and eagle and Merapi tiger), are scattered wealth and become part of the new ecosystem formed by eruptions.

\section{d. Social Capital}

Social capital in the form of customs, local wisdom, community beliefs, internal interaction and the ability to build networks and collaborate with outsiders is a force factor in the development of the local economy. Similarly, the ability of the community to adapt to the environment (hazard) and able to rise from the downturn due to disaster is the basic capital to achieve the success of development programs. The recovery of settlement, economic and social conditions is a reflection of their resilience arising from the catastrophic eruption of Merapi eruption that has destroyed their lives.

\section{e. Economic and social institutions}

There is one economic institution and two social groups that until this time developed in Balerante Village. BUMDES as a new village economic institution established in mid-2016 BUMDES 2017 and plans to develop business wings in the field of clean water management, savings, and loan, and the development of outlets in the tourist area as a means of promotion with local products of the culinary business group and Balerante creative industry. Pokdarwis is a local institution formed to manage Balerante tourism, while DRR is a relatively old local community and has the role and function of disaster reduction. The group is one of the institutions that has produced youth as a cadre in the field of disaster in 15 hamlets.

\section{f. Transport and Infrastructure}

The Balerante Village can be accessed by four wheel passenger vehicles through paved roads from Yogyakarta, Klaten, and Solo. Transportation between hamlets in Balerante village is almost entirely asphalted since the roads in the village beside functioning as economic lane also has functioned as the evacuation route to evacuation places. All households have got connected to the government electricity grid. To meet the needs of clean water so far has been established cooperation between villages Glagaharjo, Balerante, Deles, and Panggang village to manage the needs of clean water sourced in Kali Bebeng Glaharjo region. Through the partnership of four villages, the institute formed an institute called "Paguyuban Bebeng" which coordinated the maintenance of water installation through the contribution mechanism. As a village belonging to disaster-prone areas, Balerante Village has also built early warning system (EWS) in the form of tower buildings, building observations that serve as a tool for detection of Merapi activity.

\section{g. Tours}

Balerante Village is currently one of the tourist destinations that come from outside the region. There are several attractions that become a mainstay, namely: Kali Talang River Area (Talang River), mountain bike trails, and disaster museum. Kali Talang Tourist Area which is currently an "Ikon" Balerante Tourism Village, occupies an area of approximately 3 hectares, located on the edge of the Woro River and located inside within the TNGM. Attractions in the complex area are 2 units of a bamboo building (gazebo) that protrudes over the lip Kaliworo cliffs with a depth of approximately 25 meters. The two bamboo bridges in addition to functioning as a place to selfie, as well as the most strategic location to see the figure of Merapi and the basic beauty of Kali Talang flanked by displaying upstream. Another interesting attraction is the bamboo bridge (bamboo bridge) that crossed above the tourist area, so it becomes an attraction when the community bikes down the bridge with high speed across the bridge. Tourism Object Kali Talang in addition to the basic beauty and cliff figure flanking it, there is a giant water channel that resembles a gutter of water with andesite stone base. Track Bicycle Gunung Kali Talang (Kali Talang Bike Parak) in Balerante which extends from TNGM area and finish Posko Merapi Observation Station is one of favorite track for mountain bike community. The mountain bike community apart from Yogyakarta and Klaten areas also comes from Java Island and Sumatera, considering that Kalitalang Bike Park is in the same area as Klangon Gravity Park which is the track that belongs to Glagaharjo area of DIY Province.

\section{h. Economic institutions and business groups}

From the results of the study shows that after the eruption of Merapi eruption in 2010 occurred the transformation of women's work in some villages affected by Merapi. Womendominated women (housewives) who initially worked in the plantation sector and took care of households, as family economic pressures shifted to developing various types of food and handicraft businesses. From the identification, results indicate that there are 15 groups of a various food business in Balerante Village, including criping (miscellaneous, mushroom, banana, cassava), mini rempeyek, wet cakes, soy milk drink industry, in 9 hamlets. Problems faced by such household scale industries include the limited production aids (oil drainage, plastic cup cover, plastic cover/packing branch), and marketing of the product. Efforts made to promote the production of the group include the exhibition, culinary festival at the district level, and entrusted in the stalls of tourist areas.

\section{i. Farms}

Before the eruption, Merapi, farms, and plantations became a major commodity in Balerante. Almost all households cultivate cattle Until now the number of cattle a number of approximately 3000 head and 200 tail of them is an aid for the community in 5 hamlets affected directly.

\section{j. Population}


The results of the identification showed the number of Balerante population in 2017 (July 2017) of 1950 consisting of 980 people $(50.3 \%)$ and the female population 970 people $(49.7 \%), 41.5 \%$ of the population were concentrated in 2 hamlets Balerante $25.4 \%$ (495 people / 1616 households) and side scattered in 12 other villages. Based on the type of work, $32.56 \%$ (635 people) of the population worked as farmers/planters with $16 \%$ (312 male) and 16.56\% (323 female) female proportions. Another fact shows the proportion of unemployed people reaching $31.74 \%$ (619 people) of the total population, so it should be considered to create and develop productive enterprises according to their capacity as well as the potential of available natural resources. Judging from the education level $21.68 \%$ of Balerante residents finish primary school or the equivalent, education level 14, 26\% not / not yet in school.The level of junior high school education is $7.95 \%$, SLTA 3, 3\% Adapaun residents who have education up to university (strata I, II, III, and Strata) $0.46 \%$ (9 persons)

\section{Problems and Challenges of Development}

Based on the identification of perpetrators of PEL and identification of local potential, and the results of a series of discussions with the parties at the village and district there are problems that can reconsideration as a road map to accelerate the development of tourism village Balerante. Some of these problems are: a) the geographic position within the KRB and adjacent to TNGM, b) the legality manager tours, c) a partnership, d) has not integrated the industry as part of tourism development, e) the limited capacity of local human resources (see Table.)

Table 2. Problems and Challenges of Development

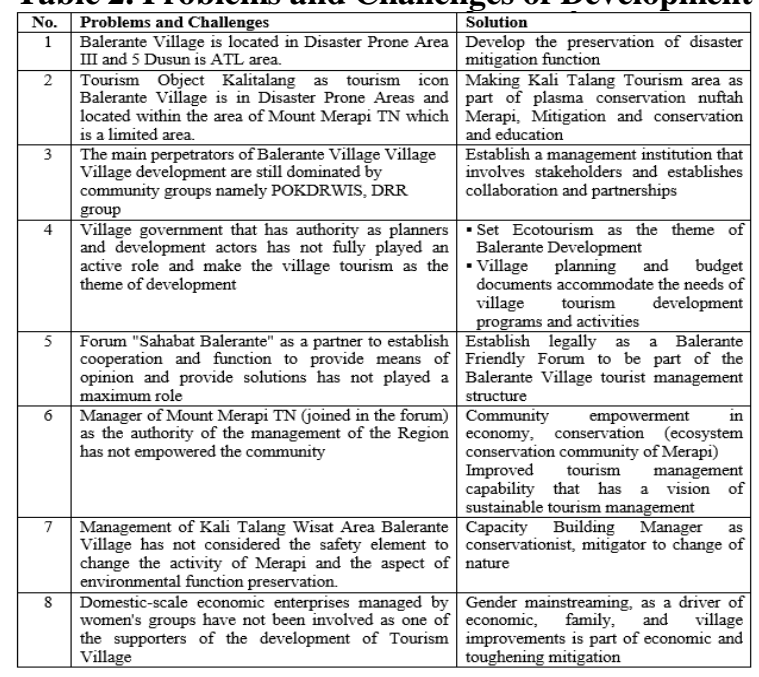

\section{Strategy}

The LED strategy for accelerating Balerante's development as a Tourism Village is based on the development of theory and analysis results on the organization of the business or the parties involved, local potential and development challenges and challenges. Some considerations of strategy development are as follows.

a). The Village Authority has the authority to plan and implement the development

b). Geographical position of the village which is located in KRB Merapi and in direct contact with Mount Merapi National Park (TNGM) c). Tourism Area (tourism object) which is located in TNGM Area

d). Open acceptance and position of Balerante Village within the Tourism Destination Region of Yogyakarta and Central Java Provinces

e). The uniqueness of the attractions

f). The diversity of local economic enterprises and the existence of BUMDes Institutions

Based on the description above, the strategy developed rural tourism development in Balerante not concentrated on selling the beauty and uniqueness of the landscape, but also develop the local economy, conservation and mitigation activities. All four of these activities into the supporting pillars of the development of the Tourism Village Balerante, interlinked and as a form of participation and involvement local communities, increase community resilience and disaster risk facing the Merapi ecosystem conservation and increasing the competitiveness of the local economy. Adapaun strategy formulation that is structured in the vision, strategy, programs and activities described as follows.

a. Vision, Realizing Balerante as a Community-Based Ecotourism Destination.

\section{b. Strategy,}

Strategy I: Developing natural and cultural tourism The main objective of the Strategy 1 is Developing the potential of natural selection and Museum Site Disaster Revitalization through program planning, partnership, and revitalization of museums disaster.

Table 3. Strategy I: Building a Region Nature and Culture

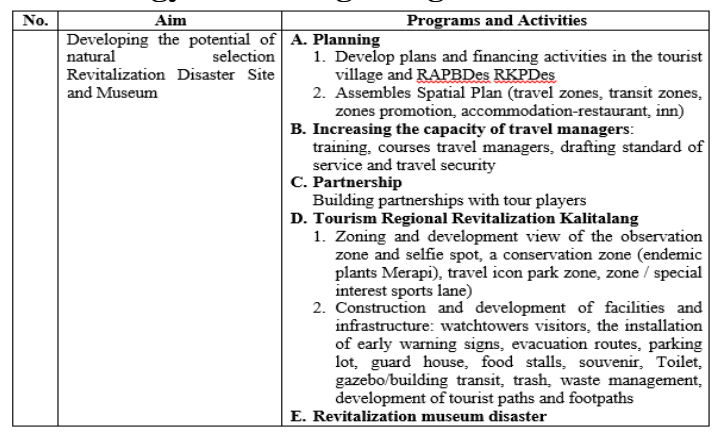

Strategy II: Delivering sustainable environment and disaster resilient village. I1 Strategy objectives to achieve this goal is a program that will develop environmental conservation and disaster mitigation.

Table 4. Strategy II: Delivering Environment Balerante Lestari and Resilient Village Disaster

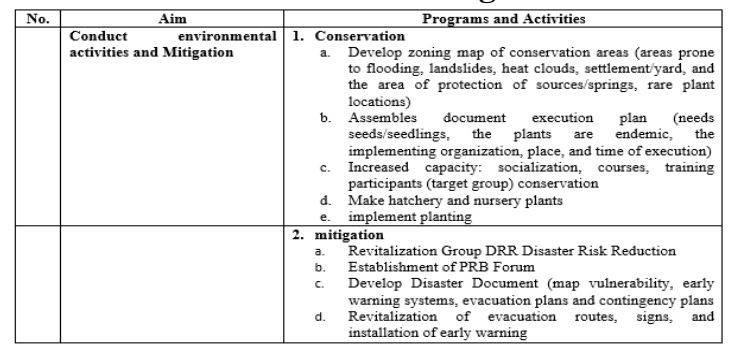

Strategy I II: developing competitiveness of the local economy. The goal of this strategy is to develop micro and medium enterprises as one part of tourism village products with appropriate marketing strategies. The program that 
will be developed is the development of local economy, especially small scale home industry which is supported by the village economic institution that is BUMDes.

Table 5. STRATEGY III: Developing Local Economic

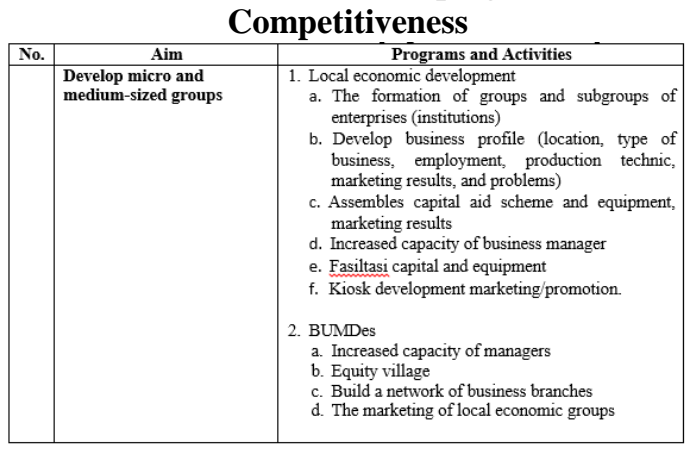

\section{Key Success Factors}

LED as a development strategy is a process that prioritizes the involvement of local community actors as development actors in collaboration and partnerships with other parties (private sector, NGOs, PT and other business actors) to optimize local potentials. The success of LED will be indicated through the creation of an expansion of employment and striving opportunities while maintaining environmental preservation. In the context of realizing the vision and mission in the development of Balerante Tourism Village, several key success factors are as follows. First, the commitment of the Balerante Village Government as the main actors. The commitment is reflected in the development of Tourism Village as part of the village development plan. This will be reflected in the document of the Village Development Planberifat, both medium and annual. Second, active involvement of local communities in various tourism activities. Third, the ability of managers in (branding of attractions, culinary and creative industries, festivals and promotions). Fourth, provide facilities and infrastructure to create comfort and security of tourists.

\section{Conclusion}

a. Merapi charm, nature landscape is the local economic potential Desabalerante which can be used as a tourist attraction.

b. Balerante village layout that is in the development of Disaster-Prone Areas (KRB) and is bordered by Mount Merapi National Park, the Travel models that can be developed as part of education mitigation of disaster risk reduction, ecosystem preservation trim and improving the competitiveness of the local economy.

c. Local economic potential includes ease of accessibility, to be located in Yogyakarta-Jawatengan travel destinations, creative industries (culinary, batik) be the primary consideration for the integrated campaign for the actors and stakeholders involved.

d. LED as a development strategy is a process that prioritizes the active involvement of local communities as development actors establish collaboration and partnership with other parties (private sector, NGOs, university and other businesses) to optimize local potential. PEL sustainability will be indicated through the creation of the expansion of employment and business opportunities while promoting environmental conservation. Referring to the principles and stages of LED then Wisa Balerante village development strategy is as follows.

- Establish a vision as a goal to be achieved, namely: Delivering Rural-Based Ecotourism Balerante As the Ecotourism Destination to achieve its visions.

- To achieve realize the vision, the strategy which will be pursued are: Developing a Tourism Village Nature and Culture, Creating Sustainable, Resilient Balerante Village Disaster and Achieve the Competitive Local Economy.

\section{SUGGESTIONS}

a. Balerante Village Government as the main actors must have a commitment to put the development of Tourism Village as part of village development plan and structure in the document of Village Development Plan both medium and annual.

b. The Balerante Village Government shall legally stipulate the Tourism Manager with the local leaders as representatives of the community representatives, especially the women's groups.

c. Tourism Village Management should always innovate by developing diversification and defensins tourism products (branding and differentiation of attractions, diversification of culinary products and creative industries, promotions through print media and social media, and festivals).

d. District Government and Village Government should facilitate the development and development of tourism facilities and infrastructure to provide tourist convenience, comfort, and security.

\section{REFERENCES}

[1] Amyrin 2000. Qualitative Methods

[2] Andrej Udovc, Anton Perpar. (2007). Role Of Rural Tourism For Development Of Rural Areas s. Journal of Central European Agriculture. Volume 8 (2007) No. 2 (223-228). http://www.researchgate.net/publication/27202273

[3] Bappenas and BNPB, 2011. The Action Plan for the Rehabilitation and Reconstruction of Post-Disaster eruption of Mount Merapi in Yogyakarta and Central Java province Years 2011-2013. Bappenas and BNPB, Jakarta.

[4] Budiharsono, S. 2015. Local Economic Development and Local To Enhance Competitiveness of Regions. Bogor) https://www.academia.edu/11332782/

Pengembangan_Ekonomi_Lokal_dan_Daerah_untuk_Me ningkatkan_Daya_Saing_Daerah

[5] Denman, Richard. 2001. Guidelines For CommunityBased Ecotourism Development. WWF International. July 2001

[6] Dewi, Made Heny U., Chafis Fandeli, M. Baiquni. 2013. Rural Development Participation of Local CommunityBased Tourism in the Tourism Village Jatiluwih Tabanan, Bali. Kawistara Volume 3 No. 2, August 17th, 2013 Pages 117-226

[7] Edy Susilo, M., Prayudi and Heti Erawawi, 2016. Approach Engagement Stakeholders in the Tourism Village Development. Journal of Science 
Communication. Vol. 2, May-August 2016 137-150 things.

[8] Irshad, Humaira. 2010. Rural Tourism-An Overview. Government Alberta. Government of Rural Development. http://www1.agric.gov.ab.ca/\$Department/deptdocs.nsf/al 1/csi13476/\$FILE/Rural-Tourism.pdf )

[9] Compass, 2017. Tourism Village stretched, Kampung Thematic Starting Attractive Travelers. Tuesday, July 25, 2017. Page 23.

[10] Pose, Rodriguez, Sylvia Tijmstra. 20015 . Local Economic Development as an alternative approach to economic development in Sub-Saharan Africa (A report for the World Bank). http://siteresources.worldbank.org/INTLED/Resources/33 9650-1144099718914/AltOverviev.pdf Downloaded July 19, 2017, At 21:00

[11] Pramesti, Olivia Lewi 2012). Minimal, Role of Women in Tourism. National Geographic Indonesia. Accessed August 9, 2017 from http: // National geographic.co.id/berita/2012/minim-peran-perempuan in tourism
[12] Rustiadi, E, sunsun Saefulhakim, Dyah R. Panuju. 2011. Planning and development of the region. Yayasan Pustaka Obor Indonesia. Jakarta

[13] Sevila, Consuela., Et al. 1993. Introduction to Research Methods. Tuwu Alimudin translator. UI Press. Jakarta

[14] Suansri, P. 2003. Community-Based Tourism (Hand Book). Responsible Ecological Social Tour-REST. Thailand.

[15] Wijayanti, Anastasia Ratna W., 2013. Changes in Public Works Sebgai Due From Disaster: A Case Study of Tourism Region Tour Mount Merapi Volcano Umbulharjo village of Cangkringan Sleman. Journal of Urban and Regional Planning. Vol. 24 No. 1, April 201h, hlmn 19-34.

[16] Wimbardana, R., et al. 2014. In tegrasi Socio-Economic Rehabilitation Population When Mount Merapi in 2010 Toward Recovery Planning. WP: 7 No Date: April 2014 ISSN : 2406-7865.

[17] World Bank, 2016. Indonesia Economic Quarterly. October 2016 